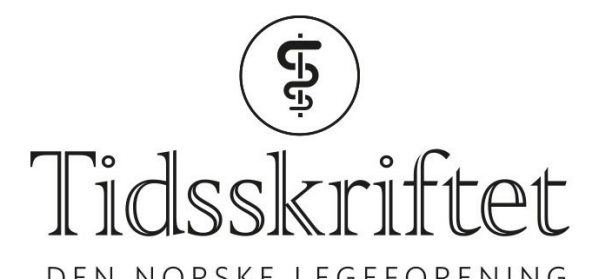

DEN NORSKE LEGEFORENING

\title{
Søvn, arbeid og overlevelse ved multippel sklerose
}

DOKTORAVHANDLINGER

HANNE MARIE BØE LUNDE

E-post: hmbl75@gmail.com

Søvnforstyrrelser er hyppige ved multippel sklerose. Under halvparten av MS-pasientene er yrkesaktive etter om lag 19 års sykdomsvarighet.

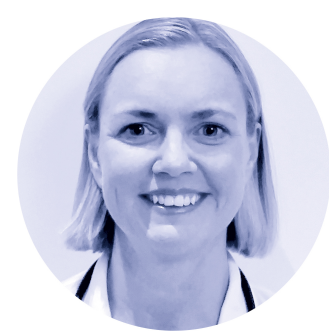

Foto: Gustav Refshus

Pasientsentrerte utfall ved multippel sklerose er lite undersøkt. I mitt doktorgradsarbeid undersøkte vi konsekvenser av multippel sklerose på søvn, arbeid og overlevelse. I en insidensbasert pasient-kontroll-studie undersøkte vi prevalens og selvrapporterte risikofaktorer for redusert søvnkvalitet. Syv av ti pasienter med multippel sklerose opplevde søvnvansker. Redusert søvnkvalitet var assosiert med kjønn (kvinne), bruk av immunmodulerende medisiner og redusert psykologisk livskvalitet.

I en tverrsnittsunders $\varnothing$ kelse unders $ø$ kte vi deretter yrkesdeltagelse og assosierte faktorer ved multippel sklerose. Etter om lag 19 års sykdomsvarighet var $45 \%$ av MS-pasientene yrkesaktive, de fleste deltidsarbeidende. Yrkesdeltagelse var assosiert med lavere aldere ved sykdomsdebut, kortere sykdomsvarighet, høyere utdanning, lavere invaliditetsgrad og fatigue.

I en prospektiv studie undersøkte vi overlevelse ved multippel sklerose hos alle med sykdomsdebut i perioden 1953-2012 i Hordaland. Gjennomsnittlig levealder i 2012 var 75 år, og $56 \%$ døde av relaterte konsekvenser til multippel sklerose. Pasientene hadde høyere dødelighet $(2,7)$ enn normalbefolkningen, men en bedring i overlevelse ble observert.

I studiene unders $ø$ kte vi viktige sider ved den totale sykdomsbyrden ved multippel sklerose. Økt kunnskap om søvn, arbeid og overlevelse kan på sikt trolig føre til bedring av pasienthelse og pasienttilfredshet. 


\section{Disputas}

Hanne Marie Bøe Lunde disputerte for ph.d-graden ved Universitetet i Bergen 3.11.2017. Tittelen på avhandlingen er Patient-centered outcomes in multiple sclerosis - Results from observational studies on sleep, employment and survival.

Publisert: 26. juni 2018. Tidsskr Nor Legeforen. DOI: 10.4045/tidsskr.18.0175

(C) Tidsskrift for Den norske legeforening 2020. Lastet ned fra tidsskriftet.no 